Ulasan IImiah

\title{
PELUANG MINYAK MENTAH SAWIT SEBAGAI BAHAN SEDIAAN FARMASI
}

OPPORTINITIES FOR CRUDE PALM OIL PHARMACEUTICAL PREPARATIONS

\author{
Fauziati, Hermanto, Fitriani \\ Balai Riset dan Standardisasi Industri Samarinda \\ Jl. MT.Haryono/Banggeris No.1 Samarinda \\ Alamat Email : fauziati8@gmail.com
}

Diterima :21-10-2019

Direvisi : 22-11-2019

Disetujui : 19-12-2019

\begin{abstract}
ABSTRAK
Minyak sawit mentah mengandung senyawa aktif yang sangat berguna bagi kesehatan tubuh manusia, komposisi senyawa bio aktif pada sawit mentah (CPO) antara lain vitamin E, karatenoid, fitosterol, squalene, phospholipid, Co enzyme, polyphenolik. Fitosterol merupakan steroida (sterol) yang terdapat di dalam tanaman dan mempunyai struktur yang mirip dengan kolesterol, tetapi fitosterol mengandung gugus etil pada rantai cabangnya. Tujuan penulisan ilmiah ini adalah untuk menginformasikan tentang senyawa bioaktif yang terkandung dalam CPO merupakan produk utama dalam pengolahan minyak sawit dan isolasi kandungan fitosterol dalam minyak mentah CPO dari minyak sawit sebagai bahan sediaan farmasi . Pada tanaman kelapa sawit terdapat lebih dari 40 senyawa sterol yang didominasi oleh tiga bentuk utama dari fitosterol, yaitu beta sitosterol, compesterol dan stigmasterol. Kegunaan fitosterol adalah menurunkan kadar kolesterol didalam darah dan mencegah penyakit jantung. Asam lemak linoleat dan oleat dapat menurunkan kadar kolesterol menjadi normal,sedangkan alfa tokoferol dapat menurunkan kadar kolesterol LDL yang mana LDL tersebut dapat teroksidasi dan mengakibatkan rusaknya pembuluh darah dan dapat timbul plak pada dinding pembuluh darah yang berakibat penyakit jantung.
\end{abstract}

Kata Kunci : fitosterol, kolesterol, minyak sawit mentah (CPO), senyawa bio aktif

\section{ABSTRACT}

Crude palm oil contains active compounds that are very useful for human health, the composition of bio active compounds in crude palm oil (CPO), including vitamin E, caratenoid, fitosterol, squalene, phospholipid, Co enzyme, polyphenolik. Phytosterols are steroids (sterols) found in plants and have a structure similar to cholesterol, but phytosterols contain ethyl groups in their branch chains. . The purpose of science writing here is to inform about the bioactive compounds contained in CPO which are the main products in the processing of palm oil and the isolation of phytosterols in CPO crude oil from palm oil as pharmaceutical preparations. In oil palm plants there are more than 40 sterol compounds which are dominated by three main forms of phytosterols, namely beta sitosterol, compesterol and stigmasterol. The use of phytosterols is to reduce cholesterol levels in the blood and prevent heart disease. Linoleic and oleic fatty acids can reduce cholesterol levels to normal, while alpha tocopherol can reduce LDL cholesterol levels where LDL can be oxidized and cause damage to blood vessels and plaque on the walls of blood vessels that can cause heart disease.

Keywords: phytosterols, cholesterol, crude palm oil (CPO), bio active compound

\section{PENDAHULUAN}

- anaman sawit (Eleis Guineensis Jaca) merupakan salah satu jenis tanaman komoditi perkebunan yang paling banyak diminati oleh usaha perkebunan, tidak hanya di Indonesia tetapi juga diseluruh dunia. Industri perkebunan dan pengolahan sawit 
adalah industri yang memegang peranan yang penting bagi perekonomian Indonesia, ekspor minyak kelapa sawit menghasilkan devisa dalam jumlah besar dan industri ini juga membuka peluang dan kesempatan bekerja bagi jutaan masyarakat Indonesia. Statistik Kementan (2017) mencatat luasan lahan areal sawit di Indonesia saat ini adalah 14,31 juta Ha, luasan tersebut terdiri dari perkebunan milik swasta seluas 7,79 juta $\mathrm{Ha}$, perkebunan rakyat 5,81 juta $\mathrm{Ha}$ dan perkebunan milik negara seluas $713 \mathrm{Ha}$. Menurut citra satelit, tutupan tanaman kelapa sawit seluas 16,83 juta $\mathrm{Ha}$, sedangkan jika merujuk pada data hasil koordinasi supervisi KPK maka luas areal perizinan kelapa sawit yang sudah diterbitkan sekitar 20 juta Ha sebagaimana terlihat pada Gambar 1 di bawah ini :

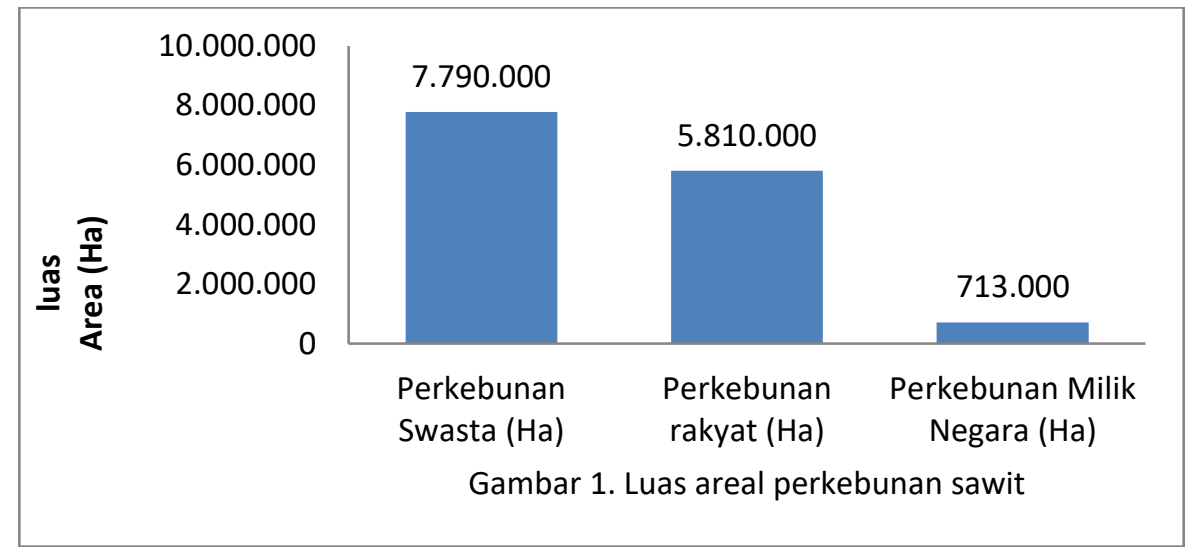

Sumber : Statistik Kementan 2017

Gambar 1. Luas Areal Perkebunan Sawit Indonesia

Tujuan penulisan imiah adalah untuk menginformasikan tentang Isolasi kandungan fitosterol dalam minyak mentah CPO dari minyak sawit sebagai bahan sediaan farmasi memberikan tantangan yang besar dalam rangka memanfaatkan bahan alami sebagai bahan obat-obatan. Dan aplikasi hasil isolasi senyawa fitosterol dalam minyak mentah (CPO) pada produk obat (incapsulasi) dan memanfaatkan senyawa bioaktif dari minyak sawit (fitosterol) sebagai bahan farmasi.

Provinsi Kalimantan Timur memiliki areal kelapa sawit dengan luas mencapai 1.150.078 Ha, dimana luasan areal tersebut terdiri dari $277.034 \mathrm{Ha}$ sebagai tanaman plasma/rakyat, 14.402 Ha milik BUMN sebagai inti dan 858.642 Ha Perkebunan Besar Swasta (Dinas Perkebunan Prop. Kaltim, 2017). Dengan luasan areal kelapa sawit tersebut dapat memproduksi TBS (Tandan Buah Segar) sebesar 11.418.110 ton , dari sejumlah perusahaan perkebunan besar swasta yang telah memperoleh izin lokasi dan yang telah beroperasi membangun kebun dalam skala yang luas baru sebanyak \pm 344 perusahaan minyak sawit CPO.

Pada saat ini areal tanaman kelapa sawit di Provinsi Kalimantan Timur terpusat di beberapa Kabupaten, yaitu : Kabupaten Kutai Timur, Kutai Kartanegara dan Paser Penajam Utara, sedangkan di beberapa Kabupaten dan kota lainnya masih dalam luasan terbatas. Data luas perkebunan kelapa sawit di Kalimantan Timur terus mengalami peningkatan signifikan, bahkan hingga akhir 2017 mencapai 1.208.697 hektar." (Dinas Perkebunan Provinsi Kaltim, 2018). 


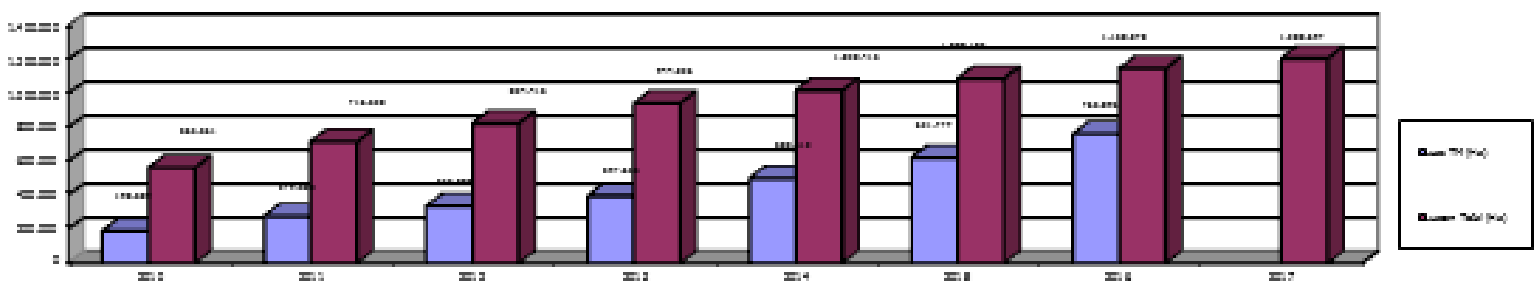

Sumber : Dinas Perkebunan Provinsi Kalimantan Timur 2017

Gambar 2. Luas Areal Kelapa Sawit Tahun 2010-2016

\section{Senyawa Bio Aktif Pada CPO (Crude Palm Oil)}

CPO adalah produk utama dalam pengolahan minyak sawit disamping minyak inti sawit yang didapatkan dengan pengepresan buah kelapa sawit, bewarna kuning jingga kemerahmerahan , asam lemak bebas 5\%, beta karoten (Vitamin E 800-900 ppm). Sugito (2001) dalam Ibrahim Agil (2010). Indonesia memiliki sumber daya dan potensi senyawa aktif yang sangat besar dan berlimpah, salah satunya adalah adanya hasil samping industri pengolahan minyak goreng, hasil samping ini berupa distilat asam lemak minyak sawit (DALMS). DALMS ini memiliki kandungan senyawa aktif berupa asam lemak dan gliserida sebanyak $96,1 \%$ serta komponen minor bioaktif sebagai tokoferol dan tokotrienol $0,48 \%$, fitisterol $0,37 \%$, skualen $0,76 \%$ dan hidrokarbon lain 0,71\% (Gapoor et al., 2002). Penelitian lain menyebutkan bahwa DALMS memiliki komposisi komponen bioaktif yang berada pada fraksi tidak tersabunkan (FTT) (Khatoon et al., 2010). DALMS merupakan by produk pada saat proses pemurnian CPO secara fisik, hasil penelitian Estiasih et al. (2013) menunjukan pada proses saponifikasi secara optimum akan menghasilkan FTT yang mengandung tokoferol $0,06 \%$, tokotienol $0,73 \%$, skualen $1,14 \%$ dan fitosterol $9,18 \%$. Minyak sawit mentah (CPO) pun mengandung senyawa bioaktif. Komposisi senyawa bio aktif pada sawit mentah (CPO) seperti pada Tabel 1 berikut :

Tabel 1 : Komponen Bio Aktif Pada CPO

\begin{tabular}{clc}
\hline No. & Pitonutrient & Jumlah (ppm ) \\
\hline 1. & Poliphenolik & $40-70$ \\
2. & Co-Enzim & $10-80$ \\
3. & Pospolipid & $20-100$ \\
4. & Squalen & $250-540$ \\
5. & Fitosterol & $300-620$ \\
6. & Karetenoid & $500-700$ \\
7. & Vitamin E & $600-1000$ \\
\hline
\end{tabular}

Sumber : (Estiasih et al., 2013)

\section{Peluang Industri Minyak Kelapa Sawit}

Dalam bidang pertanian, minyak sawit merupakan industri terpenting di Indonesia yang menyumbang di antara 1,5 - 2,5 persen terhadap total produk domestik bruto (PDB). Sumbangan ekspor sawit juga merupakan salah satu yang tertinggi di antara lima komoditas lainnya.

Minyak kelapa sawit adalah minyak sayur (nabati) yang mengandung lemak jenuh dan tak jenuh ${ }_{L}$ beta-karoten, vitamin $E$ serta diduga memiliki efek antioksidan. Salah satu kandungan yang terdapat dalam minyak kelapa sawit adalah fitosterol, yakni senyawa yang 
secara alamiah membantu menurunkan kolesterol. Nutrisi tersebut juga mempunyai manfaat kesehatan seperti meningkatkan fungsi otak, mengurangi risiko pembentukan gumpalan darah di arteri (efek antitrombotik), dan menurunkan tekanan darah. Berdasarkan kandungan yang terdapat pada minyak sawit dan besarnya produksi minyak sawit di Kalimantan Timur, maka terbuka peluang usaha untuk pengembangan industri hilir minyak sawit terutama kandungan bio aktif fitosterol sebagai bahan sediaan farmasi. Pada saat ini pemanfaatan Distilat Asam Lemak Minyak Sawit lebih banyak di gunakan sebagai sumber asam lemak bukan sebagai sumber senyawa bioaktif (Estiasih et al., 2015)

Saat ini Indonesia melakukan impor bahan sediaan farmasi dengan nilai ekonomi yang cukup besar. Menurut data impor produk industri farmasi secara keseluruhan (data statistik Kemendag RI tahun 2016) adalah sebagai berikut :

Tabel 2 : Data Impor Produk Industri Farmasi Secara Keseluruhan Kemendag RI Tahun2016

\begin{tabular}{|c|c|c|c|c|c|c|}
\hline \multicolumn{7}{|c|}{ Nilai ( Juta US \$) } \\
\hline No. & $\mathrm{HS}$ & 2012 & 2013 & 2014 & 2015 & 2016 \\
\hline 32 & 30 & 578 & 655,9 & 710,2 & 739,0 & 801,8 \\
\hline
\end{tabular}

Sumber : Kemendag RI 2016

Berdasarkan data impor produk industri farmasi pada tabel 2 tersebut diatas terjadi kenaikan nilai impor dari tahun 2012 sampai dengan tahun 2016 dengan nilai trend kenaikannya sebesar $8,01 \%$. Selama ini produk industri farmasi obat kolesterol masih diimpor dari luar negeri berupa obat sintetis atau disebut dengan obat paten. Dengan melihat produksi minyak sawit yang besar dan dengan memanfaatkan potensi provinsi Kalimantan Timur, seperti kelapa sawit yang dapat dibuat/dimanfaatkan sebagai bahan sediaan farmasi yang dapat mengurangi impor (subtitusi impor). Fitosterol yang terkandung dalam minyak sawit mampu untuk mensubtitusi obat-obatan sesuai dengan peruntukannya yaitu sebagai obat anti kolesterol.

Manfaat bagi pemerintah adalah menumbuhkan industri baru untuk bahan sediaan obat-obatan khususnya anti kolesterol. Sejalan pula dengan amanat Undang-Undang Republik Indonesia Nomor 3 tahun 2014 tentang Perindustrian, Pasal 3 yaitu Perindustrian diselenggarakan dengan tujuan mewujudkan Industri yang mandiri, berdaya saing dan maju, serta keberhasilan program industri hijau, sehingga dengan adanya penelitian ini menjadi salah satu solusi sumber daya alam yang bersifat terbarukan (renewable) akan mendukung pembangunan yang berkelanjutan.

Secara khusus industri minyak sawit mentah dapat memanfaatkan sumber bahan baku yang dapat memberikan nilai tambah yang besar karena dapat menghasilkan bahan sediaan obat- obatan yaitu fitosterol sebagai obat anti kolesterol.

\section{Inovasi dan Diversifikasi}

Prokduktivitas kelapa sawit lebih tinggi dibanding jenis tanaman lain dalam menghasilkan minyak nabati . Tingkat produksi minyak sawit mencapai 3,6 ton perhektar per tahun untuk periode 1970-2017. Badan Pengkajian dan Penerapan Teknologi (BPPT) tahun 2019 
,memperkirakan produksi sawit akan mencapai 51,7 Juta ton pada tahun 2025 . Kondisi ini bisa berlanjut sampai tahun 2030 bila terjadi over suplay, hal ini bisa mengakibatkan kelebuhan pasokan yang akhirnya akan terjadi harga jual produk menjadi rendah. Tetapi bila kelebihan produksi dapat diserap pasar maka berakibat sangat baik bagi industri maupun petani .

\section{Fitosterol Minyak Kelapa Sawit}

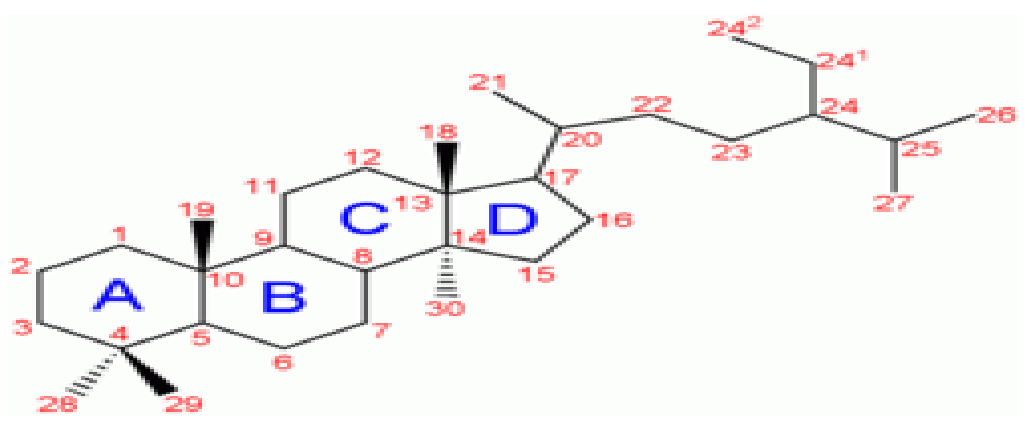

Gambar 3. Struktur fitosterol

Menurut Pateh et al,2019 bahwa fitosterol adalah sterol nabati dengan struktur mirip dengan kolesterol mengandung gugus etil ( $\mathrm{C} 2 \mathrm{H} 5-$ ) pada rantai cabangnya , terdiri dari 2830 atom dengan steroid sebagai rangka struktur dengan gugus hidroksil menempel C-3 dari cicin A,dan rantai alifatik pada atom C17 dari cincin D . Pada tanaman terdapat lebih dari 40 senyawa sterol yang didominasi oleh tiga bentuk utama dari fitosterol yaitu betasitosterol,compesterol dan stigmasterol. Asam lemak linoleat dan oleat mengakibatkan kolesterol pada tingkat normal

Fitosterol adalah sterol nabati dengan struktur mirip kolesterol, terdiri dari 28 hingga 30 atom dengan steroid sebagai rangka struktur dengan gugus hidroksil menempel pada C-3 dari cincin A, dan rantai alifatik pada atom C-17 dari cincin D (Pateh et al., 2009) senyawa ini tidak larut dalam air, tetapi larut dalam alkohol. Fitosterol merupakan steroida (sterol) yang terdapat didalam tanaman dan mempunyai struktur yang mirip dengan kolesterol ,tetapi fitosterol mengandung gugus etil pada rantai cabangnya. Pada tanaman terdapat lebih dari 40 senyawa sterol yang didominasi oleh tiga bentuk utama dari Fitosterol, yaitu beta-stesitosterol, compesterol dan stigmasterol.

Fitosterol menghambat penyerapan dan meningkatkan ekskresi, sedangkan asam lemak tidak jenuh, khususnya asam lemak linoleat dan oleat, menjadikan kolesterol pada tingkat kadar yang normal. Alfatokoferol menurunkan kadar kolesterol LDL serum dan menghambat oksidasi kolesterol LDL di mana LDL-teroksidasi pemicu rusaknya pembuluh darah, penebalan pembuluh darah, dan penyebab timbulnya plak yang merupakan salah satu faktor pemicu penyakit jantung.

Sterol nabati atau fitosterol secara alami membentuk alkohol steroid yang hanya ditemukan pada tanaman. Derivat minyak ini merupakan unsur penting yang terdapat pada membran sel tanaman dan dapat diklasifikasikan menjadi tiga grup berdasarkan proses biosintesis dan strukturnya, yaitu 4-desmethyl sterols, 4-methyl sterols dan 4,4dimethylsterols. Meskipun demikian, hanya 4-desmethyl sterols yang dapat menurunkan LDL dan total serum pada manusia. Beberapa biasanya ditemukan 4-desmethyl sterols termasuk ß- sitosterol, kampesterol, stigmasterol dan brasikasterol (Vissers, M. N., Zock P. L., Meijer G. W., Katan M. B. 2000 dan Sierksma A, Weststrate J. A., and Meijer G. W. 1999). 
Fitosterol dapat menghambat penyerapan kolesterol dari usus dan dapat menghambat sintesis kolesterol dengan memodifikasi aktifitas enzim hepatitis acetyl -coa carboxylase dan cholesterol 7-hydroxylase (Silalahi,J,2006) .

\section{Jenis Fitosterol}

Menurut Santoso ( 2013 ), ada dua macam fitosterol yaitu :

1. Sterols yang mempunyai ikatan ganda pada cincin sterol, sterol pada umumnya terdapat pada tumbuhan dan makanan adalah sitosterol dan compesterol.

2. Stanol tidak mempunyai ikatan ganda pada cincin sterolnya ikatan ganda pada cincin sterolnya,stanol pada umumnya juga terdapat pada tumbuhan tetapi hanya $10 \%$ dari total diet fitosterol. Stano tanaman adalah bagian dari terhidrogenasidari sterols tanaman, namun keberadaannya dialam lebih sedikit dari pada sterol .

Fitosterol digolongkan menjadi tiga kelompok utama yaitu: $\beta$ sitosterol, stigmasterol dan compesterol. Adapun sitostanol merupakan fitosterol yang termasuk ke dalam komponen compesterol, ergosterol, brassicasterol, delta-7-stigmasteroldan delta -7avenasterol. Food and Drug Administration (FDA) telah mengakui peran fitosterol untuk menurunkan kolesterol dan fitosterol sendiri telah dikelompokkan ke dalam bahan tambahan makanan yang aman (Generally Recognized as Safe-GRAS) sampai batas $20 \%$ dalam suatu produk makanan (Anonim, 2010).

\section{Fungsi fitosterol}

(1) menurunkan kadar kolesterol di dalam darah dan mencegah penyakit jantung, sehingga sangat bermanfaat bagi kesehatan manusia; Fitosterol menghambat absorpsi kolesterol dari usus, meningkatkan ekskresi garam-garam empedu, atau menghindarkan esterifikasi kolesterol dalam mukosa intestinal. Fitosterol dapat menghambat sintesis kolesterol dengan memodifikasi aktivitas enzim hepatic acetyl-coa carboxylase dan cholesterol 7 - hydroxylase. (Silalahi, J. 2006). Mengonsumsi 1-2 gr fitosterol dalam sehari dapat menurunkan $6-20 \%$ kolesterol tubuh dan dapat mencegah penyakit jantung. (2) meningkatkan ekskresi kolesterol, sehingga dapat menurunkan penyerapan kolesterol total. Fitosterol juga dapat memperbaiki regulasi kolesterol darah pada tingkat normal. Mekanisme perlindungan jantung oleh fitosterol telah dimulai dari usus. (3) Mencegah penyakit kanker. Berdasarkan Europian Journal Of Clinical Nutrition pada tahun 2009, fitosterol diketahui dapat mencegah penyakit beberapa jenis kanker, antara lain : kanker paru, kanker ovarium, dan kanker usus. Dari penelitian tersebut diketahui fitosterol dapat mencegah sel kanker tumbuh dan menyebar didalam tubuh, seperti cara kerja antioksidan, (4) menjaga kesehatan kulit. Fitosterol dapat mencegah rusaknya kolagen akibat pengaruh lingkungan yang tidak sehat /kurang baik. Mengkonsumsi makanan yang mengandung fitosterol dapat membuat awet muda dan mencegah penuaan dini.

\section{Rata-rata Konsumsi Fitosterol}

Beberapa ahli gizi menyarankan konsumsi fitosterol sebanyak minimal 1 gram per hari. Konsumsi fitosterol di Amerika rata-rata mencapai 200-300 mg/hari, sedangkan di Jepang konsumsinya mencapai 300-500 mg/hari. Kaum vegetarian dapat mengonsumsi fitosterol hingga $1000 \mathrm{mg} /$ hari, sedangkan untuk non-vegetarian biasa mengonsumsi fitosterol sebanyak 345 mg/hari. Food and Drugs Administration (FDA) dan Badan Pengawas Obat dan Makanan RI telah menyetujui klaim kesehatan fitosterol dalam menurunkan risiko penyakit jantung dengan asupan fitosterol bentuk ester minimal $1.3 \mathrm{~g} / \mathrm{hari}$ terbagi dalam dua sajian sebagai bagian dari diet rendah lemak jenuh dan rendah kolesterol (FDA 2010, BPOM 
2011). Pada berbagai penelitian, intervensi fitosterol tanpa diet rendah lemak juga dapat menurunkan kolesterol (Wu et al. 2009, Sialvera 2012).

\section{Aplikasi Produk Fitosterol}

Produk fitosterol yang dihasilkan umumnya diaplikasikan pada produk-produk seperti : Tropicana Slim non fat, Margarin dan Minyak goreng.

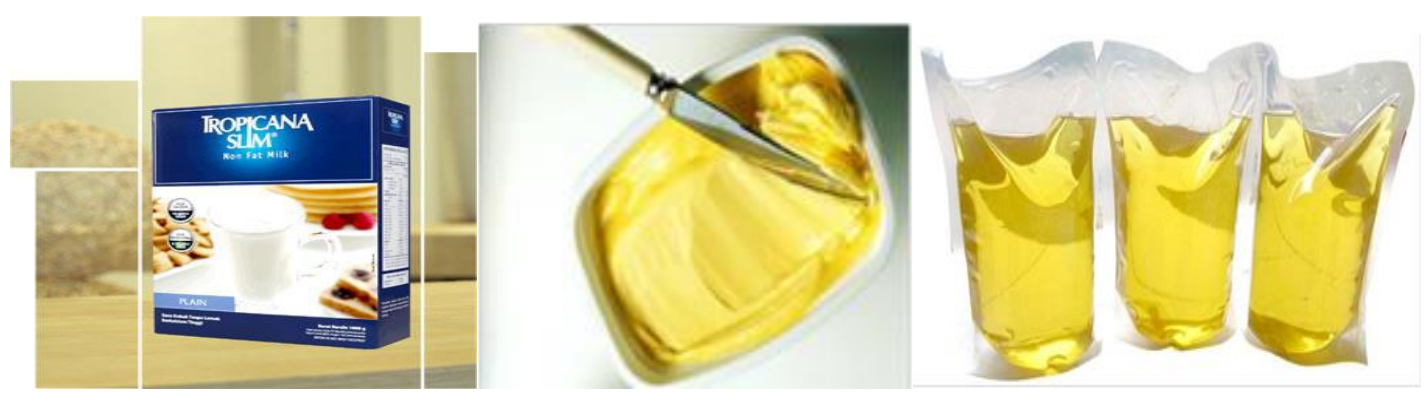

Gambar 4. Contoh produk kaya fitosterol

Fitosterol merupakan jenis lemak yang berasal dari sumber makanan nabati. Meskipun sama-sama dari golongan lemak, fitosterol memilki fungsi yang berbeda dengan saudaranya yaitu kolestrol. Kolestrol merupakan jenis sterol yang berasal dari pangan hewani yang dapat meningkatkan kadar kolesterol plasma darah, khususnya bagi penderita hiperkolesterolemia. Sedangkan fitosterol justru sebaliknya karena dapat menurunkan kadar kolesterol plasma darah. Penyakit jantung erat kaitannya dengan kolesterol, karena bila jumlah kolesterol terlalu banyak di dalam darah maka dapat terbentuk endapan di dinding pembuluh darah yang mengakibatkan terjadinya penyempitan pada pembuluh darah jantung.

Fitosterol juga dapat memperbaiki regulasi kolesterol darah pada tingkat yang normal. Salah satu fitosterol yaitu sitoastanol sudah dibuktikan secara klinis dapat menurunkan kadar kolesterol plasma dan LDL-kolesterol sampai 10-14 persen. Bahkan Food and Drug Administration (FDA), 2010 , telah mengakui peran fitosterol untuk menurunkan kolesterol dan fitosterol sendiri telah dikelompokkan ke dalam bahan tambahan makanan yang aman (Generally Recognized as Safe-GRAS) sampai batas 20\% dalam suatu produk makanan.

\section{Proses Isolasi Fitosterol Dari Minyak Kelapa Sawit}

Proses isolasi fitostrerol diawali dengan analisa kualitatif minyak sawit kasar (CPO), melakukan isolasi fitosterol dengan komponen senyawa aktif nya dan analisa mutu fitosterol dan turunannya serta aplikasi fitosterol sebagai bahan sediaan farmasi ke industri farmasi.

- Bahan yang digunakan antara lain : Minyak kasar (CPO) dari industri kelapa sawit di PPU Kaltim, etanol absolute, $\mathrm{KOH}$, petroleum eter, Lieberman burchad, n-phentanol diperoleh dari distributor bahan kimia dan aquades.

- Peralatan yang digunakan antara lain : Satu set alat reflux, saringan vacum, neraca analitik, termometer, penangas, labu ekstraksi, corong pemisah, kertas saring, pipet volume, gelas ukur, wadah sampel (produk), tabung reaksi. 
Diagram Alir 1.

Proses Pembuatan Ekstrak Pekat Senyawa Fitosterol

Ekstrak minyak kasar ( CPO )<smiles>[123I]</smiles>

Dimasukkan kedalam tabung reksi

Ditambahkan petroleum eter

Dikocok

Dipisahkan lapisan eter yang terbentuk

Ditambahkan pereaksi Lieberman Buchard

(steroid + ditunjukkan dengan terbentuknya warna hijau kebiruan)

Ektrak pekat fitosterol

\section{Diagram alir 2.}

Ekstraksi Fitosterol pekat menghasilkan sigmasterol

Ekstrak pekat fitosterol sebanyak $5 \mathrm{~g}$

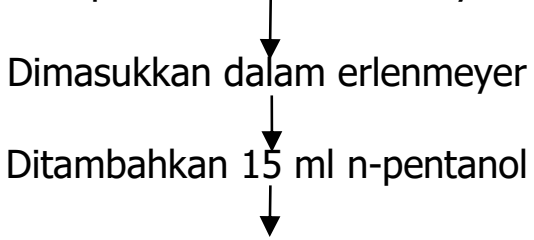

Dipanaskan dalam penangas air $\left(60^{\circ} \mathrm{C}\right)$ sambil diaduk selama 10 menit

Didinginkan larutan dalam pènangas es ( ruangan gelap )

Kristal sigmasterol

Disaring menggunakan alat vakum dengan kertas saring

Kristal

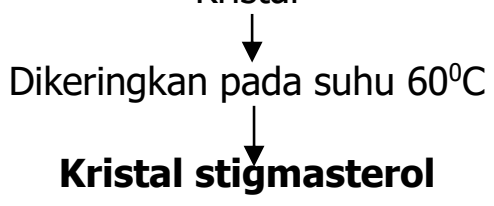

\section{Diagram Alir 3.}

Uji kualitatif senyawa fitosterol

Ekstrak minyak kasar (CPO) sebanyak $\pm 0,3 \mathrm{~g}$ 


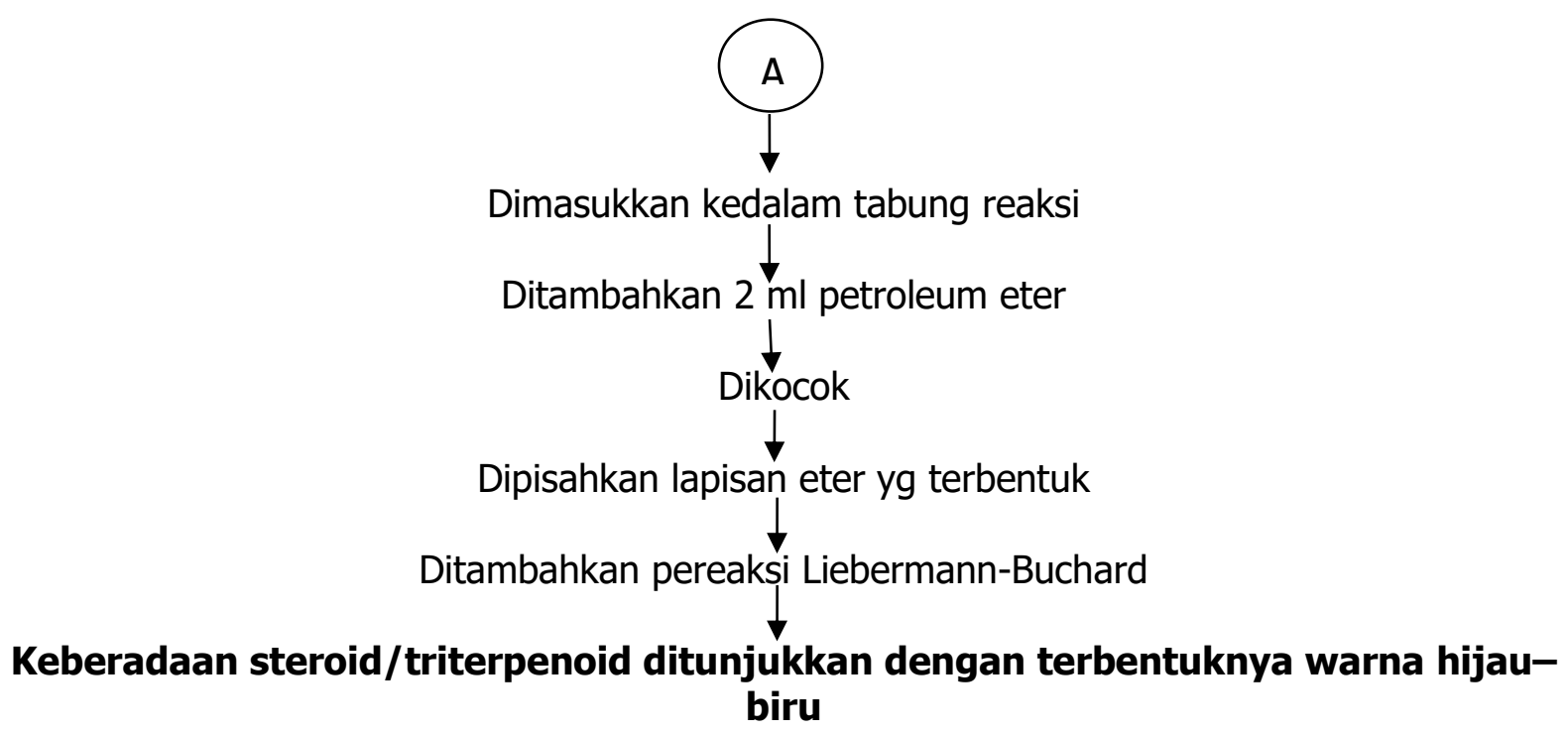

\section{Kolesterol}

Kolesterol adalah metabolit yang mengandung lemak sterol (waxy steroid) yang ditemukan pada membrane sel dan disirkulasikan dalam plasma darah. Merupakan sejenis lipid yang merupakan molekul lemak atau yang menyerupainya. Kolesterol merupakan jenis khusus lipid yang disebut steroid. (Michelle A, Hopkins J, McLaughlin CW, Johnson S, Warner MQ, LaHart D, Wright JD. 1993).

Steroid adalah lipid yang memiliki struktur kimia khusus. Struktur ini terdiri dari 4 cincin atom karbon. Steroid lain termasuk steroid hormon seperti kotisol, estrogen, dan testosterone, semua hormon steroid ini terbuat dari perubahan struktur dasar kimia kolesterol. Selain penting untuk struktur sel hewan, kolesterol juga berfungsi sebagai prekusor untuk biosentesis hormon steroid, asam empedu dan vitamin D. Fungsi kolesterol diperlukan untuk membangun, memelihara dan memodulasi fluiditas membrane pada kisaran suhu fisiologis. Gugus hidroksil dari setiap molekul kolesterol berinteraksi dengan molekul air yang mengelilingi membrane seperti halnya kepala polar dari fosfolipid dan sphingolipid membran, sedangkan steroid besar dan rantai hidrokarbon tertanam dalam membran, disamping rantai asam lemak fosfolipid, kolesterol meningkatkan pengepakan membran, yang keduanya mengubah fuiditas membran.

( https://id.wikipedia.org/wiki/Kolesterol, 2019)

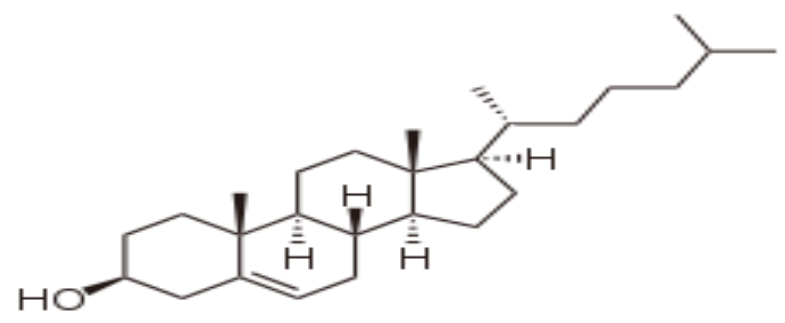

Gambar 5 : Struktur Kolesterol 


\section{Kesimpulan}

Pada tanaman kelapa sawit terdapat lebih dari 40 senyawa sterol yang didominasi oleh tiga bentuk utama dari fitosterol, yaitu beta sitosterol, compesterol dan stigmasterol. Komposisi senyawa bio aktif pada minyak sawit mentah (CPO), antara lain vitamin $\mathrm{E}$, karatenoid, fitosterol, squalene, phospholipid, Co enzyme, polyphenolik Kegunaan fitosterol menurunkan kadar kolesterol dalam darah dan mencegah penyakit jantung . Fitosterol yang terkandung dalam minyak sawit mampu untuk mensubtitusi obat-obatan sesuai dengan peruntukannya yaitu sebagai obat anti kolesterol. Dihasilkan senyawa Kristal stigmasterol hasil dari ekstraksi fitosterol dan secara kualitatif diperoleh senyawa steroid/triterpenoid.

\section{DAFTAR PUSTAKA}

Anonim. 2007. Fitosterol Lawan kolesterol, Kanker Dan Penuaan. http://www.gaya hidup sehat online.com. tgl akses 10-10-2019.

Anonim. 2010. Susu Bubuk Skim. Vitalus Nutrition Inc 4200 Meridian Street Bellingham. USA: WA 98226. http://www.vitalus.com/pdf/Milk_Products_Skim_Milk_Powder_Product InfoSheet. Tanggal akses 15-10-2019

Anonim. 2013. Fitosterol. http://kingdom149-santoz.blogspot.com/2013/02/fitosterol.html. Tanggal akses 10-10-2019

Badan Pengelola Dana Kelapa Sawit. 2018, Indonesia Tonjolkan Capain SDGs untuk Penguatan Diplomasi Sawit. https://www.bpdp.or.id/indonesia-tonjolkan-capainsdgs-untuk-penguatan-diplomasi-sawit. Tgl akses 8-10-2019.

Endang Suarna. 2006. Prospek dan Tantangan Pemanfaatan Biofuel sebagai Sumber Energi Alternatif Pengganti Minyak di Indonesia. Prosiding. Pusat Pengkajian Dan Penerapan Teknologi Konversi dan KOnservasi Energi. BPPT.

Dewanti, W., Tri. 2006. Pangan Fungsional Makanan Untuk Kesehatan. Universitas Brawijaya, Malang.

Dimas Agil. 2016. Pengaruh Asean China Free Trade Agreement (AC-FTA) Terhadap Pertumbuhan Ekonomi Lokal Indonesia. Skripsi. Hubungan International Universita Pasundan.

Dinas Pangan, Tanaman Pangan dan Hortikultura. 2017. Potensi Tanaman Kelapa Sawit Kaltim. Laporan Tahunan 2017. Dinas Pertanian Tanaman Pangan Provinsi Kaltim.

Leah, Emma. 2009. Cholesterol Lipidomics Gateway. Drug Discovery. Vol.15,no4: 333-342 doi : $10.1038 /$ lipidmaps.2009.3

Estiasih., Teti, KGS Ahmadi, Tri Dewanti W, Jaya Mahar M, A. Zaki Mubarok, Elok Zubaidah, Jhauharotul Mukhlisiyyah dan Risma Puspitasari. 2013. Bioactive Compounds of Palm Fatty Acid Distillate (PFAD) from Several Palm Oil Refineries. Advance Journal of Food Science and Technology . 5(9): 1153-1159.

FDA Food and Drugs Administration. 2010. Food Labeling; Health Claim; Phytosterols and Risk of Coronary Heart Disease; Proposed Rule. FDA, US.

Gapor, M. D. T and Sundram K. 1992. Vitamin E from Palm Oil: Its Extraction and Nutrional Properties. Lipid Technology . 4: 137-141.

Gapoor A. Hasan WHW and Sulong M. 2002. Phyto-chemical for nutraceutical from the by product of palm oil develop. 36:13-19.

Hanukoglu. 1992. Steroidogenic enzyms : structure, function and role in regulation of steroid hormone biosynthesis. J Steroid Biochem Mol Biol. 43 (8): 779-304.

Kementrian Pertanian Republik Indonesia. 2017. Buku Statistik Pertanian 2017. http://epublikasi.setjen.pertanian.go.id/arsip-perstatistikan/statistik. 
Khatoon, S., Raja RGR, and Krishna AGG. 2010. Physicochemical Characteristics and Composition Of Indian Soybean Oil Deodorizer Distilate and The Recovery Of Phytosterol. J. Am Oil Chem Soc 87 \:321-326. DOI : 10.1007/S III 746-00901499-8

Michelle., A, Hopkins, McLaughin CW, Johnson S, Warner MQ, Lahart D, Wrigth JD. 1993. Human Biology and Health. Englewood Clffs, New Jersey, USA Prentice Hall ISBN 013-981176-1 OCLC 32308337.

Oison RE. 1998. Discovery Of the lipoproteins, their role in fat transport and their significance as risk factors. J. Nutr. 128 (2 Suppl) : 439S-443S. doi: 10.1093/jn/128.2.439. PMID9478044.

Pateh., U, U, Haruna A. K, Garba, M, Iliya, Abubakar, M.S and Ambi A, A .2009. Isolation Of Stigmasterol, B-Sitosterol, and 2 Hydroxyhexadecanoid and methyl ester from rhizomes of Stylochtion lancifolius, Nig, Journal Pharm Sci, 8(1):19-25.

Parkia. 2013. Pengkajian kandungan Fitoserol Pada Tanaman Kedawung. Biodiversitas mipa uns.ac.id.

Publishing Harvard Health, "How It's made : cholesterol production in your body-Harvard Health" Diakses tanggal 2019-09-10.

Purwiyatno, H. 2014. Buku Mengenal Minyak Sawit dengan Beberapa Karakter Unggulnya. http://phariyadi.staff.ipb.ac.id. Diakses tanggal 15-10-2019.

Razin, S. dan Tully J. 1970. Cholesterol Requirement of Mycoplasmas. Journal of Bacteriology. 102(2): 306-310.

Sadava, D Hillis DM, Heiler HC, dan Berenbaum MR. 2011. The Science of Biology. 9 ${ }^{\text {th }}$ Edition. 105-114. Freeman. San Francisco.

Sialvera., TE, Pounis GD, Koutelidakis AE, Richter DJ, Yfanti G, \& Kapsokefalou M, et al. 2012. Phytosterols supplementation decreases plasma small and dense LDL levels in metabolic syn-drome patients on a westernized type diet. Nutrition, Metabolism \& Cardiovascular Di-seases, 22(10): 843-848.

Sierksma., A, Weststrate J. A, and Meijer G. W. 1999. Spreads Enriched with Plant Sterol, Either Esterified 4, 4-dimethylsterol or Free 4-desmethylsterol, and Plasma Total and LDL Cholesterol Concentration. British Journal Nutritional . 82(4): 273-282.

Silalahi, J. 2006. Makanan Fungsional. Kanisius. Yogyakarta.

Silalahi, J. 2006. Fitosterol dalam Margarin Cara Efektif Menurunkan Kolesterol. www.tempointeraktif.com. Tanggal akses 3/10/201).

Sofia Laily. 1987. Isolasi Dan Identifikasi Sterol Dari Minyak Kelapa Sawit. Skripsi. Fakultas Farmasi Universitas Erlangga .

Sweety Mehtha. 2013. Biosynthesis and Regulation of Cholesterol (with Animation). Phama Xhange. https://pharmaxchange.info/2013/09/biosynthesis-and-regulation-ofcholesterol -animation

Vissers, M. N., Zock P. L, Meijer G. W, Katan M. B. 2000. Effect of Plant Sterol from Rice Brand Oil and Triterpene Alcohols from Sheanut Oil on Serum Lipoprotein Concentrations in Humans. American Journal Clinic Nutritional . 72:1510-1515.

Wu Tm Fu J, Yang Y, Zhang L, dan Han J. 2009. The effects of phytosterols/stanols on blood lipid profiles: a systematic review with meta-analysis. Asia Pac J Clin Nutr. 18(2): 179-186. 